\title{
The Hans Tausen drill: design, performance, further developments and some lessons learned
}

\author{
Sigfús J. JOHNSEN, ${ }^{1}$ Steffen Bo HANSEN, ${ }^{1}$ Simon G. SHELDON, ${ }^{1}$ \\ Dorthe DAHL-JENSEN, ${ }^{1}$ Jørgen P. STEFFENSEN, ${ }^{1}$ Laurent AUGUSTIN, ${ }^{2}$ Paul JOURNÉ, ${ }^{2}$ \\ Olivier ALEMANY, ${ }^{2}$ Henry RUFLI, ${ }^{3}$ Jakob SCHWANDER, ${ }^{3}$ Nobuhiko AZUMA, ${ }^{4}$ \\ Hideaki MOTOYAMA, ${ }^{5}$ Trevor POPP, ${ }^{1,6}$ Pavel TALALAY, ${ }^{7}$ \\ Thorsteinn THORSTEINSSON, ${ }^{8}$ Frank WILHELMS, ${ }^{9}$ Victor ZAGORODNOV ${ }^{10}$ \\ ${ }^{1}$ The Niels Bohr Institute, Blegdamsvej 17, DK-2100 Copenhagen, Denmark \\ E-mail: sigfus@gfy.ku.dk \\ ${ }^{2}$ Laboratoire de Glaciologie et Géophysique de I'Environnement du CNRS (associé à I'Université Joseph Fourier-Grenoble I), \\ 54 rue Molière, BP 96, 38402 Saint-Martin-d'Hères Cedex, France \\ ${ }^{3}$ Physics Institute, University of Bern, Sidlerstrasse 5, CH-3012 Bern, Switzerland \\ ${ }^{4}$ Nagaoka University of Technology, Kamitomioka cho 1603-1, Nagaoka 940-2188, Japan \\ ${ }^{5}$ National Institute of Polar Research, Kaga 1-9-10, Itabashi-ku, Tokyo 173-8515, Japan \\ ${ }^{6}$ Desert Research Institute, 2215 Raggio Parkway, Reno, NV 89512-1095, USA \\ ${ }^{7}$ St Petersburg Mining Institute, 199026 St Petersburg, Russia \\ ${ }^{8}$ National Energy Authority, Grensásvegur 8, IS-108 Reykjavík, Iceland \\ ${ }^{9}$ Alfred Wegener Institute for Polar and Marine Research, PO Box 120161, D-27515 Bremerhaven, Germany \\ ${ }^{10}$ Byrd Polar Research Center, The Ohio State University, 1090 Carmack Road, Columbus, OH 43210-1002, USA
}

\begin{abstract}
In the mid-1990s, excellent results from the GRIP and GISP2 deep drilling projects in Greenland opened up funding for continued ice-coring efforts in Antarctica (EPICA) and Greenland (NorthGRIP). The Glaciology Group of the Niels Bohr Institute, University of Copenhagen, was assigned the task of providing drilling capability for these projects, as it had done for the GRIP project. The group decided to further simplify existing deep drill designs for better reliability and ease of handling. The drill design decided upon was successfully tested on Hans Tausen Ice Cap, Peary Land, Greenland, in 1995. The $5.0 \mathrm{~m}$ long Hans Tausen (HT) drill was a prototype for the $\sim 11 \mathrm{~m}$ long EPICA and NorthGRIP versions of the drill which were mechanically identical to the HT drill except for a much longer core barrel and chips chamber. These drills could deliver up to $4 \mathrm{~m}$ long ice cores after some design improvements had been introduced. The Berkner Island (Antarctica) drill is also an extended HT drill capable of drilling $2 \mathrm{~m}$ long cores. The success of the mechanical design of the HT drill is manifested by over $12 \mathrm{~km}$ of good-quality ice cores drilled by the HT drill and its derivatives since 1995 .
\end{abstract}

\section{INTRODUCTION}

In 1994 a new palaeoclimatic European Union (EU) project 'European Project for Ice Coring in Antarctica' (EPICA) was initiated, in part building on the momentum of the successful European Greenland Icecore Project (GRIP) (GRIP Members, 1993) both in terms of drilling technology and scientific know-how. The plan was to recover deep cores at Dome C (EPICA Dome C (EDC) core (EPICA Community Members, 2004) and in Dronning Maud Land (EPICA DML (EDML) core) (EPICA Community Members, 2006). The Glaciology Group (now the Ice and Climate Group) of the University of Copenhagen (UCPH) that had organized the GRIP drilling project was assigned the task of providing ice-drilling capability for the EPICA project. The drill should also serve the North Greenland Icecore Project (NorthGRIP) (DahlJensen and others, 2002; NorthGRIP Members, 2004), a new deep drilling project in Greenland, organized and significantly funded by the UCPH group. This opened up the possibility of testing new design features in Greenland prior to the next drilling season in Antarctica, as well as training new drillers for Antarctic work. All these projects became highly successful in terms of drilling performance and scientific outcomes.
The ISTUK drill (Johnsen and others, 1994) used in the GRIP project was considered unsuited for the very cold Antarctic temperatures, due to both the battery pack and some special rubber gaskets that would not seal properly at the very low temperatures expected in Antarctica. Thus it was decided to aim at a simpler drill design for the EPICA project. This had been fully specified by the UCPH group when they accepted the task. The EPICA steering committee requested that L. Augustin (L.A.) and P. Journé (P.J.), of Laboratoire de Glaciologie et Géophysique de I'Environnement (LGGE), Grenoble, France, should work with S.J. Johnsen (S.J.J.) and S.B. Hansen (S.B.H.) on the drilling task, and the Italian group from Ente per le Nuove tecnologie, I'Energia e I'Ambiente (ENEA) should build new drill electronics under the supervision of the late N. Gundestrup from the UCPH group, who was also the chairman of the EPICA drilling group.

Successful experiments with the 3 in $(7.62 \mathrm{~cm}) \mathrm{UCPH}$ shallow drill (Johnsen and others, 1980) in a wet hole on Summit Greenland in 1993 pointed to a fully acceptable solution. The shallow drill was modified for drilling in a wet hole by removing the upper half of the $2 \mathrm{~m}$ long core barrel and making a space for a chips chamber with a filter at the top. The drive shaft passed through the chips chamber to the core barrel. This design was used in the Icelandic 


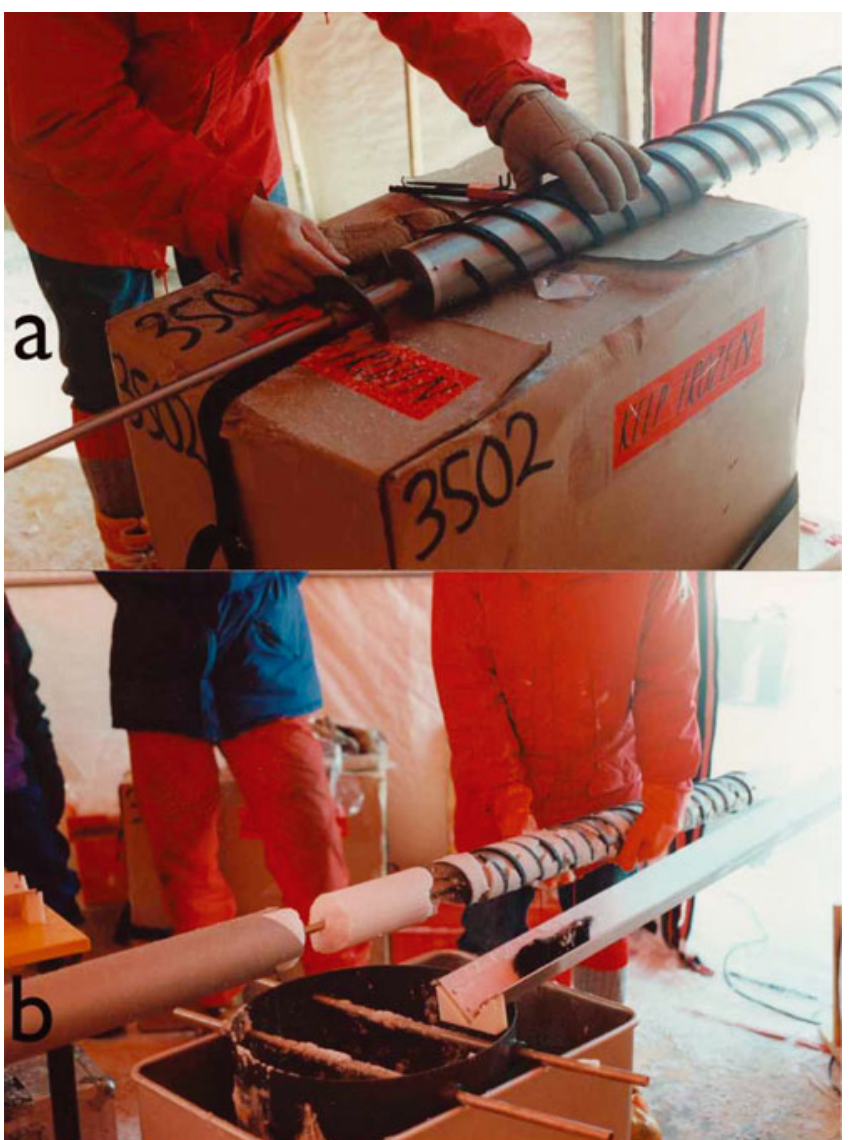

Fig. 1. The modified UCPH shallow drill. (a) Drive shaft, booster and shortened inner core barrel. (b) After a normal successful run, chips chamber, booster and spirals are packed with chips. The chips fall into the black PVC jug with a fine filter at bottom; the liquid is collected in the aluminium bucket.

Bardarbunga drill (Ámason and others, 1974; Theodórsson, 1976) and was later adopted by the designers of the Japanese Antarctic Research Expedition (JARE) deep drill (Suzuki and Shimbori, 1986; Suzuki, 1994; Tanaka and others, 1994). In the bottom of the chips chamber a Suzuki booster (Hancock, 1994) for compacting the chips was mounted on the drive shaft (Fig. 1).

The test showed that the usual cracking of a dry drilled core after passing a certain depth (presumably due to less
Table 1. Hans Tausen drill, main dimensions (mm). ID: inner diameter; OD: outer diameter

\begin{tabular}{lclr}
\hline Hole diameter, wet & 129.6 & Outer-barrel length & 1910 \\
Hole diameter, dry & 126.0 & Hollow-shaft ID & 20.0 \\
Core diameter & 98.0 & Hollow-shaft OD & 30.0 \\
Drill-head ID & 99.0 & Chips-chamber ID & 110.3 \\
Core-barrel ID & 100.0 & Chips-chamber OD & 114.3 \\
Core-barrel OD & 104.0 & Chips-chamber length & 1586 \\
Core-barrel length & 1732 & Pressure-tube length & 600 \\
Outer-barrel ID & 113.0 & Anti-torque length & 900 \\
Outer-barrel OD & 118.0 & Outer-barrels length & 3494 \\
& & & \\
\hline
\end{tabular}

manageable and increasingly finer chips) could be entirely prevented, at least to the maximum tested depth of $230 \mathrm{~m}$, by having liquid (D60 lamp oil) in the hole. At these depths the liquid only needs to cover the drill and seems to lubricate the entire chips transport process. Figure 2 demonstrates the core quality before and after the liquid had been added to the hole at $160 \mathrm{~m}$ depth.

\section{MAIN DESIGN FEATURES}

Having reviewed existing mechanical drill designs in light of the drilling experience of UCHP, it was decided that the new deep drill for the EPICA and NorthGRIP projects should be based on the same concepts as the Bardarbunga drill (Árnason and others, 1974) as well as on several design features of the ISTUK and UCPH shallow drills (Johnsen and others, 1980, 1994; Gundestrup and others, 1984). The Polar Ice Coring Office (PICO) ice-coring drill (Hancock, 1994) and the JARE deep drill (Tanaka and others, 1994) were designed using similar general concepts.

The main features of the new drill (Fig. 3) were an inner core barrel with spiral flights, a $100 \mathrm{~mm}$ drill head scaled up from the shallow drill and an outer barrel with inside grooves. The cuttings were to be stored in a chips chamber at the top of the core barrel. A $30 \mathrm{~mm}$ diameter hollow shaft with several holes and a fine-mesh screen $(0.5-1.0 \mathrm{~mm})$ clamped on the outside for filtering the chips also acts as a drive shaft extending through the chips chamber. Important modifications were incorporated to ensure fast tripping (better than $1 \mathrm{~m} \mathrm{~s}^{-1}$ ) of the drill in the hole, as was the case with the ISTUK drill. This goal was achieved by having a

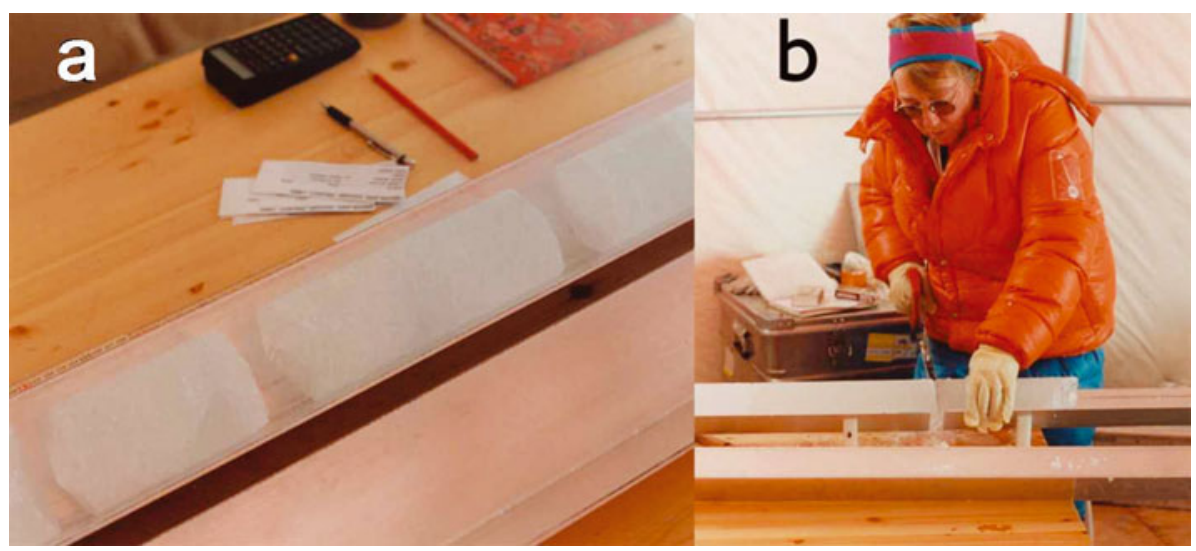

Fig. 2. Summit 1993 drill test with UCPH shallow drill: (a) broken and internally fractured core from dry drilling at $160 \mathrm{~m}$; (b) perfect unbroken core from wet drilling at a similar depth. 


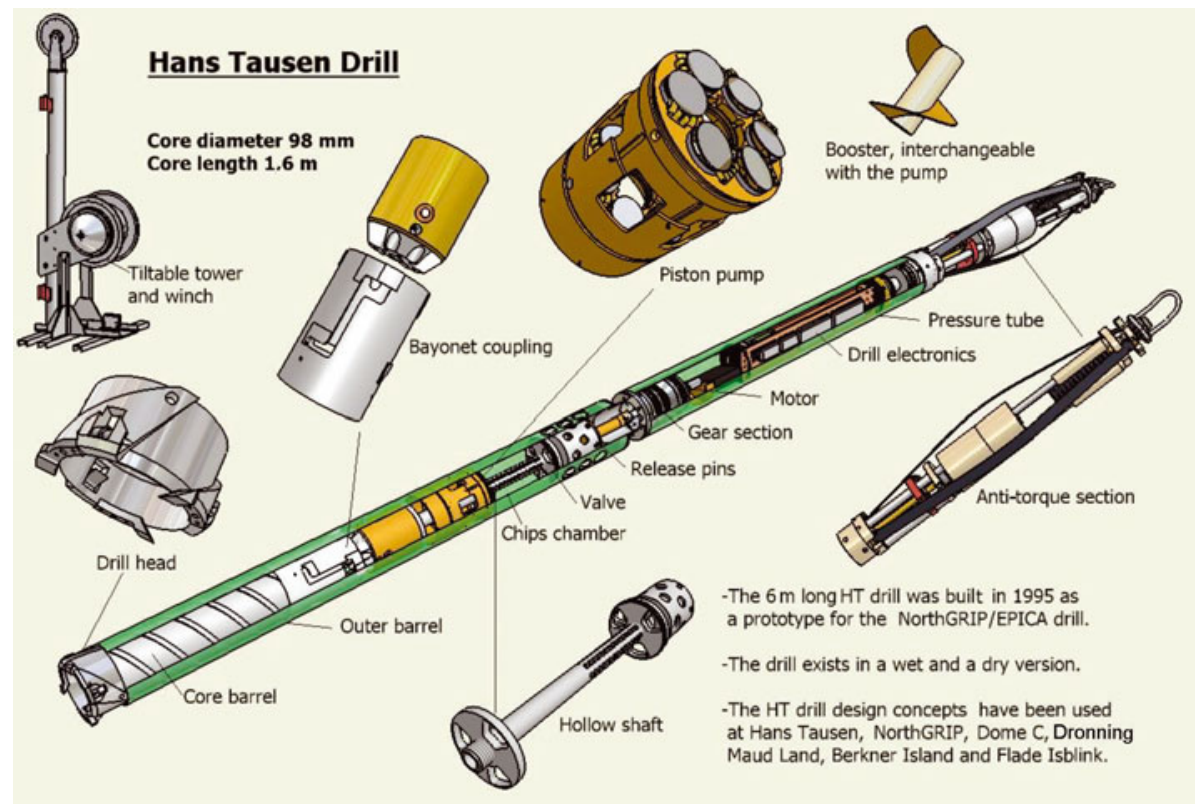

Fig. 3. The major components of the HT drill. The first version, a prototype for the deep NorthGRIP and EPICA drills, was tested on Hans Tausen Ice Cap in 1995; it did not have the pump or the bayonet coupling installed. See text for further explanation.

minimum of $5.8 \mathrm{~mm}$ clearance between the outer drill barrel and the hole wall. Furthermore, the end pistons of the chips chamber were designed as valves that could be opened (to almost one-third of the drill cross-section) and closed by rotating the drive shaft backwards and forwards. The valves were to be left open until the drilling started, so that, when lowering, the liquid can bypass the narrow, high drag zone between the outer barrel and the hole wall by flowing through a much larger cross-section inside the core barrel and the chips chamber. Easy and fast surface operations were achieved with only two operators, by using the tiltingtower concept of the UCPH shallow and ISTUK drills.

A prototype drill incorporating all these features was built in 1995. The final drawings were made by L.A. with the Euclid drafting program at LGGE in Grenoble. The tubes below the pressure tube along with the inner parts were built by subcontractors in the Grenoble area and overseen by L.A. The drill heads, cutters and shoes were made by $\mathrm{H}$. Rufli (H.R.) in Bern, Switzerland, scaled up from the UCPH shallow drill (Fig. 4). The electronic parts including motor and gear section were imported either from the UCPH shallow drill or the ISTUK drill, and the anti-torque from the ISTUK drill. The overall drill length of $5.0 \mathrm{~m}$ with the short pressure tube was inspired by the size of an existing drilling tent and also made the drill easily transportable in a Twin Otter or similar aircraft. The drill can also be modified for dry drilling; the only change needed is to mount a specially designed dry drill head with narrower cutters, also made by H.R., giving a minimum of $4 \mathrm{~mm}$ clearance between the drill and the hole wall. Table 1 lists most of the drill dimensions.

\section{THE HANS TAUSEN DRILL TEST}

Two members of the EPICA drilling group from LGGE (L.A. and P.J.) were invited to participate in the Nordic Hans Tausen Project (Hammer and others, 2001) organized by the UCPH group, where they assisted S.B.H. and S.J.J. in testing the new drill on Hans Tausen Ice Cap, Peary Land, Greenland.
The drill prototype was equipped with a Suzuki booster and a simple coupling of the core barrel, i.e. no bayonet coupling (cf. Figs 3 and 10). The drill was mounted on the shallow-drill winch base with a $3.5 \mathrm{~m}$ long tower and $400 \mathrm{~m}$ of cable (Figs 3 and $5 a$ ). The electronics were borrowed from the shallow drill, with a $160 \mathrm{~V}$ d.c. motor mounted inside a short pressure tube on the old ISTUK drill gear section. The anti-torque section was also imported from the ISTUK drill. The drill, tower and general set-up is shown in Figures 5 and 6.

As the HT dry drill head was not ready, the initial dry drilling was done with the UCPH shallow drill down to

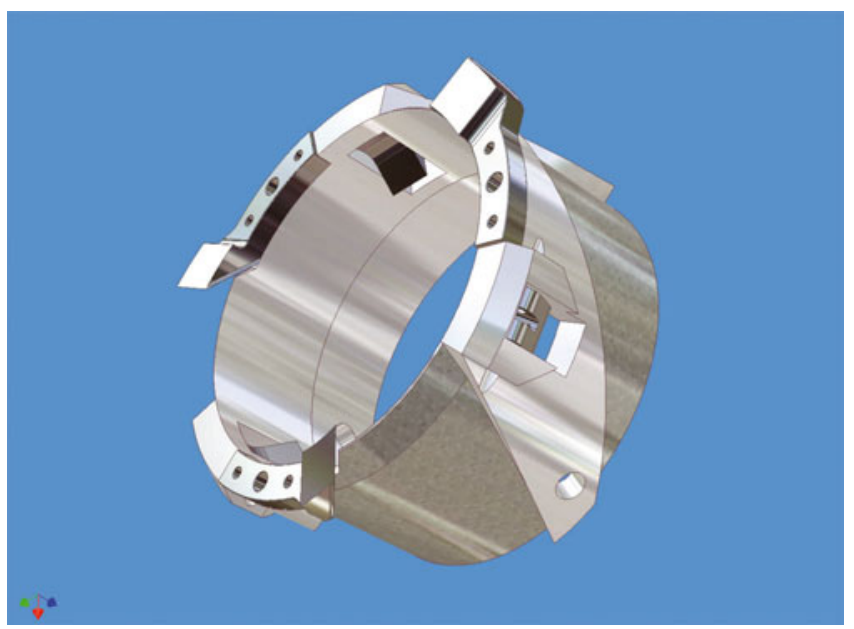

Fig. 4. The 4 in $(10.16 \mathrm{~cm})$ Hans Tausen drill head is blown up from the one used in the 3 in UCPH shallow drill. The shoes (not shown) that control the pitch are located right behind the cutters for best results. The wet and dry version are slightly different, cutting $129.6 \mathrm{~mm}$ and $126.0 \mathrm{~mm}$ holes respectively and $98 \mathrm{~mm}$ core in both cases. The cutter widths are thus $15.8 \mathrm{~mm}$ for the wet and $14.0 \mathrm{~mm}$ for dry head. The cutters normally used have a relief angle of $15^{\circ}$ and a cutting angle of $45^{\circ}$. 


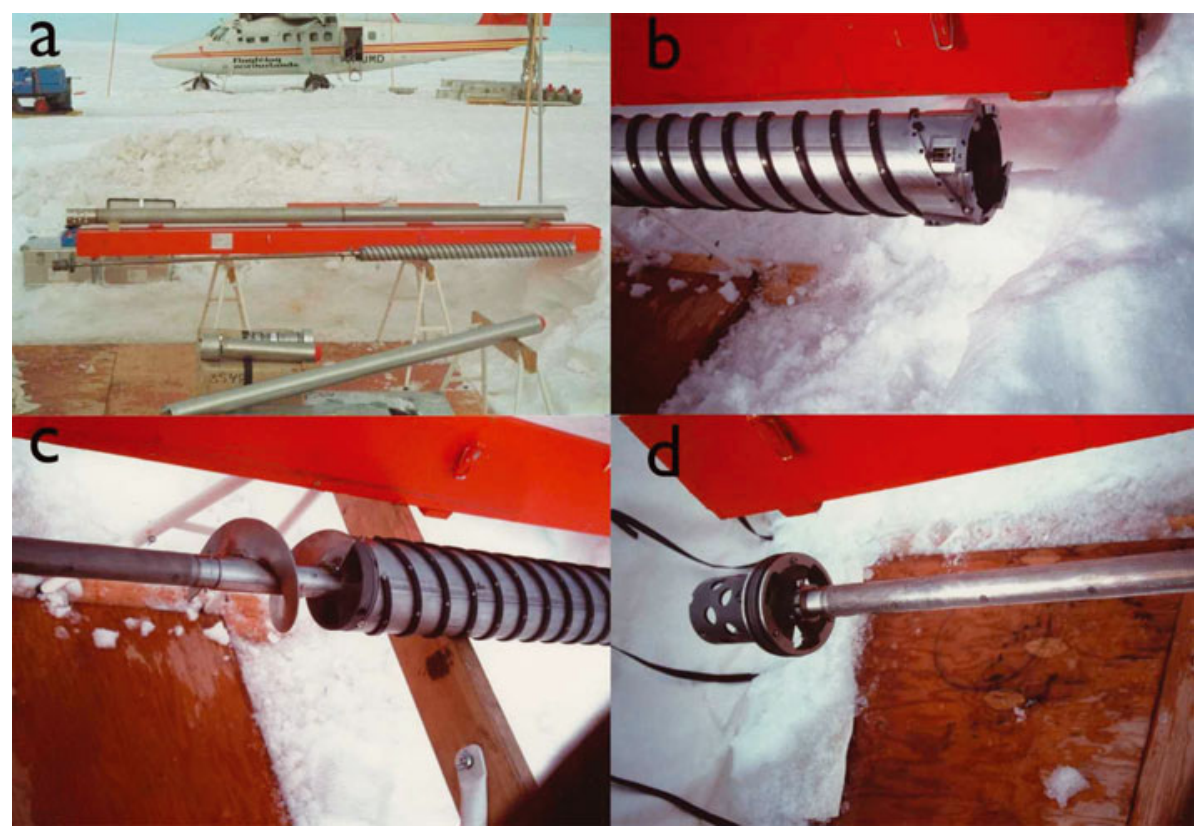

Fig. 5. From the Hans Tausen Ice Cap 1995 drill test. (a) The tubes in the foreground are the reamer units; the $3.5 \mathrm{~m}$ long outer drill barrel sits on the long transport box; on the side are the inner drill parts, hollow shaft, booster and core barrel. In the background we see the $8 \mathrm{~kW}$ generator to the left, the Twin Otter and the cargo line to the right. (b) Drill head mounted on core barrel with polyethylene spirals. The extra flights on the drill head extending to the hole wall produced immediate packing. (c) Top of core barrel, hollow shaft with filter sleeve and booster mounted. (d) Top valve and coupling cup mounted on top of hollow shaft. The valve consists of two circular discs with large specially designed openings and Teflon seals on the outside. The upper disc is fixed to the shaft, and the lower disc can rotate $120^{\circ}$ relative to the other, helped by the friction between seal and outer barrel; in the end positions the openings are either aligned or closed.

$106 \mathrm{~m}$. The hole was reamed up to $130 \mathrm{~mm}$ with the reamer set seen in Figure 5a. Three more reamers come with the drill that can ream up to $25 \mathrm{~cm}$ diameter for standard casing (Johnsen and others, 1994). As very little densifier was available, the drilling liquid used was mainly odourless lamp oil (D60). We never had more than a $50 \mathrm{~m}$ liquid column in the hole, adding new liquid when the column was lowered to $10 \mathrm{~m}$. There was no casing, so the liquid was dumped in the hole using a $50 \mathrm{~m}$ long plastic hose. Due to the low liquid density $\left(880 \mathrm{~kg} \mathrm{~m}^{-3}\right)$, the cuttings left in the hole remained at the bottom for easy retrieval in the next run, a situation the polyethylene spirals and the booster could easily cope with.

The drill test went extraordinary well, almost all the new drilling concepts worked as hoped for and we recovered $344 \mathrm{~m}$ of perfect core, with typical run length of $1.6 \mathrm{~m}$, during 3 weeks of drilling, working one daily 10 hour shift. Unexpectedly, the core quality turned out to be independent of the liquid pressure at the bottom of the hole. The ice temperature at the ice-bedrock interface was $-17^{\circ} \mathrm{C}$. The friction between drill and liquid was very close to what had been predicted by P.J.'s liquid-flow calculations, making $1 \mathrm{~m} \mathrm{~s}^{-1}$ drill velocity an easy goal to achieve, both when travelling up and down the hole.

One improvement, however, did not work as expected, but taught us a lesson. As an experiment, we extended the flights on the drill head out to the hole wall (Fig. 5b) in order to better guide the cuttings away from the cutters towards the spiral transport system. This 'improvement' made the chips pack immediately on the drill head, actually confirming earlier experiences made with the ISTUK drill. New 'improved' drill heads, manufactured later in the EPICA drilling project, with more confined conduits for guiding the chips also had the same problem. What we had achieved was to prevent free mixing of fresh cuttings and liquid, which is imperative for proper lubrication and moving of the chips. We also learned later on, when using the pump (discussed below), that the chips-liquid mixture needs constant stirring in order to avoid separation of the two components (ice and liquid), which inevitably results in blocked chip transport, hard packing of the chips on the drill head and a lost run.

\section{FURTHER DEVELOPMENTS}

During the NorthGRIP and EPICA projects, the drilling group met after each boreal and austral drilling season in order to analyze the lessons learned and to decide on possible improvements to the design. As soon as the highly successful 1995 test field season ended, the drilling group decided that the only change needed for building an efficient deep drill was to make a longer version of the HT drill with all other design features mostly unchanged. The $1.7 \mathrm{~m}$ long core barrel and the $1.6 \mathrm{~m}$ long chips chamber of the prototype HT drill should be made as long as $4 \mathrm{~m}$ each in the new deep drill in order to get sufficient core production. This drill was ready for testing at NorthGRIP in 1996 using slightly modified ISTUK electronics and the drill tower from the GRIP drilling project on Summit Greenland. At the same time we tested the new winch intended for the EPICA drilling at Dome C.

The performance of the new drill was far below our expectations. The drilled cores were long and unbroken, but the chip transport between the drill head and the chips chamber was very inefficient, leaving behind too high a proportion of the cuttings from each run, resulting in problems such as difficult penetration. In spite of the problems that summer, however, we installed the casing and managed to drill to $350 \mathrm{~m}$ at Summit. 


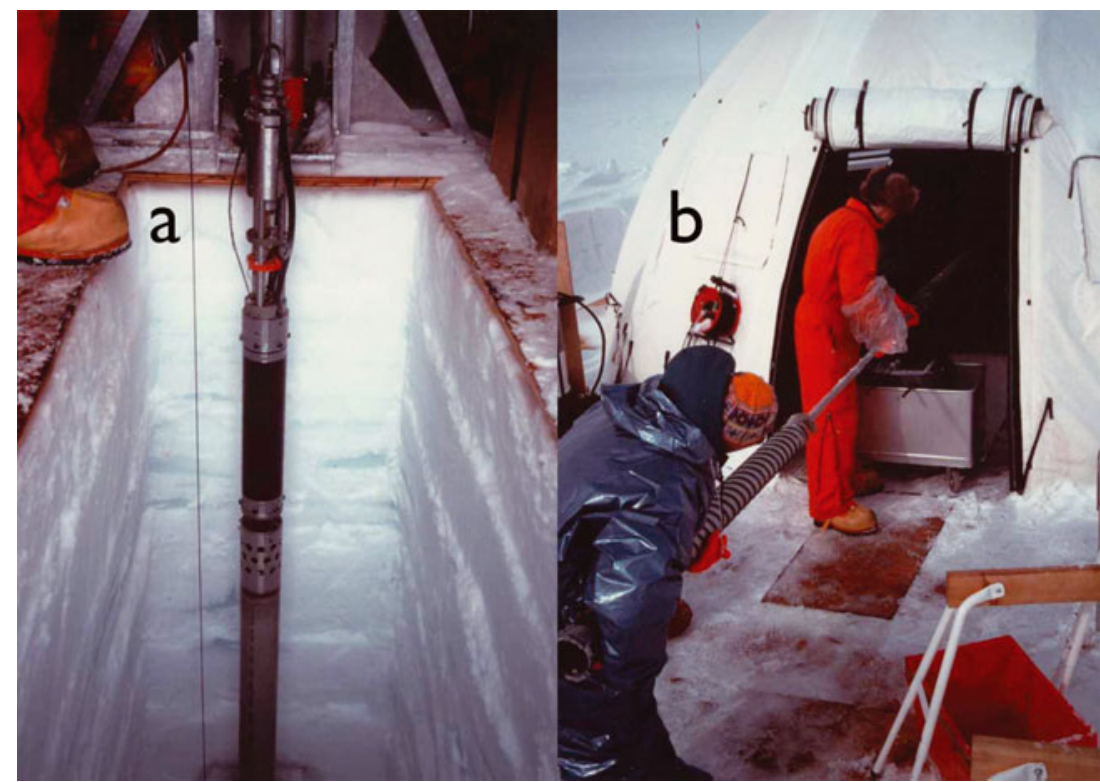

Fig. 6. Hans Tausen 1995 drill test. (a) The drill hangs in the drill pit from the shallow winch and tower unit. The base of the winch is seen at top, and the drill parts from top are anti-torque section, (short) motor section and top of chips chamber. (b) S.B.H and P.J. mount the core barrel and hollow shaft inside the drill. When this unit is pulled out, all the chips in the chips chamber will follow, with the top valve acting as piston. The rest of the drill is inside the white dome tent.

After the field season the drilling group decided on different measures to increase chip transport efficiency, such as stepping up the rotation rate from $60 \mathrm{rpm}$ to $80 \mathrm{rpm}$ and installing more efficient boosters. Another option, not considered feasible by the group at the time, was to build a pump to replace the booster, which in any case is not really pumping liquid but moving and compacting thick slush (as well as dry chips). In fact the spirals are mainly responsible for transporting the chips. Such a pump was, however, designed and built (Figs 3 and 7) by the UCPH group and installed in the drill for the NorthGRIP 1997 season. The pump is a double-action piston pump with two pistons, featuring six $30 \mathrm{~mm}$ diameter spring-loaded flap valves each, moving $2 \mathrm{~cm}$ in anti-phase inside a special sleeve fixed to the top of the grooved outer barrel (Fig. 7). The pump delivers a maximum $20 \mathrm{~L} \mathrm{~min}^{-1}$ at $60 \mathrm{rpm}$ rotation speed and allows the liquid to pass through it during descent of the drill. Another obvious advantage of the pump compared to the booster was the ability to keep all the chips inside the chips chamber even after aborted runs with only a half-full and unpacked chips chamber.

The pump immediately improved the performance of the drill and we again recovered long unbroken cores. The drilling was easy, but only just over $90 \%$ of the chips in each run were collected. This meant extra cleaning of the hole during night shifts. By going for shorter runs, 3.0-3.5 m or so, we would most likely have ensured full chip recovery as was later experienced by the EPICA Dome C drilling crew (Augustin and Antonelli, 2002). Ease of operation is another important feature of this drill system.

Two HT drills were built, one for the NorthGRIP project and one for the EPICA project (often referred to as the EPICA drill short version). A slightly longer HT-type drill with a $2.14 \mathrm{~m}$ long core barrel was also built for the Berkner Island (Antarctica) project (Mulvaney and others, 2007). That drill is also being used in the Italian Talos Dome (Antarctica) drilling project. Two pairs of long deep drills were made for the NorthGRIP and EPICA projects, with slightly different core-barrel/chips-chamber length ratios. The most recently built drills were given longer chips chambers in order to help recover more cuttings. Two of the deep drills were lost by being terminally stuck after hard packing around the drill head and a subsequent failed core break, while most of the short inner parts of the second EPICA deep drill were lost in transit from Dome C. The only remaining NorthGRIP deep drill was used to drill the EDML deep core. A new electronics package (without the batteries of the ISTUK drill) was designed and built for the NorthGRIP/EDML drill by the late N. Gundestrup, F. Wilhelms (F.W.) of the Alfred Wegener Institute, Germany, and S. Sheldon (S.S.) of the UCPH group. The HT drills were also used to deal with the warm ice encountered in both the EPICA and NorthGRIP projects due to their convenient length and easy handling. Without additional remedies the cores drilled close to bedrock were much too short. At NorthGRIP, EDC and EDML, drilling became possible again after a 'cognac bomb' (further discussed below) was installed in the chips chamber prior to each run. At EDML, novel modifications were made to the drill head and made the drilling faster. In 2006 the HT drill was used on Flade Isblink, northeast Greenland, for testing new drilling fluids. In the coming years it will also be used to recover new ice cores in Antarctica, on Roosevelt Island and in Aurora Basin. For the next deep drilling in Greenland (North Eemian) we will have to make changes to the NorthGRIP drill in order to cope with the higher viscosity of the new drilling liquids.

\section{PROBLEMS WITH DENSIFIERS}

The drilling fluid normally used was D60 mixed with Frigen $141 \mathrm{~b}$ as a densifier. This densifier has a most annoying property: it sticks to the fine chips and makes them sink to the bottom where they prevent the drilling fluid from mixing with the freshly cut chips, initiating hard packing around the 


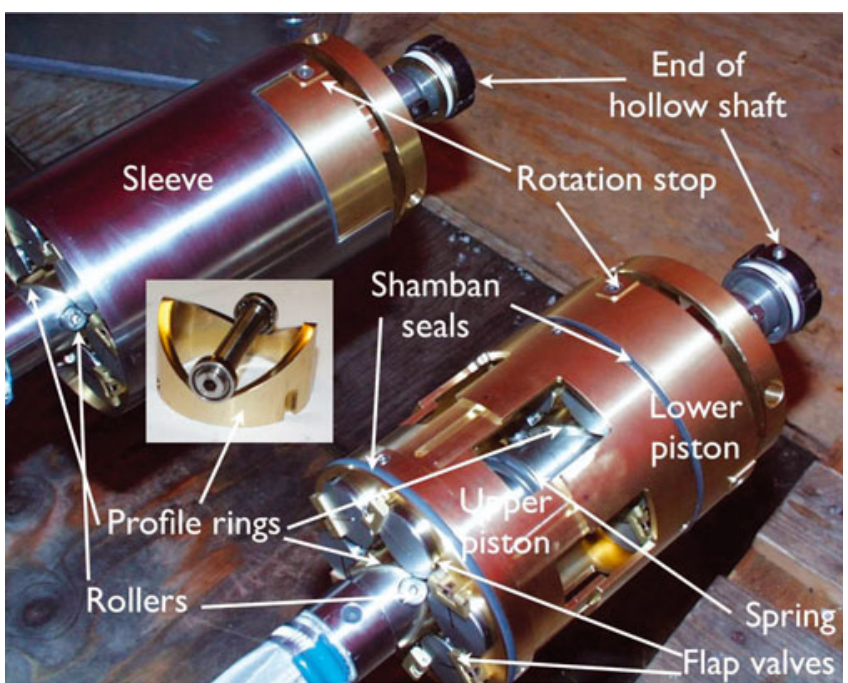

Fig. 7. Two pump assemblies mounted on the hollow shafts; one is inside the sleeve which normally is fixed to the top of the outer drill barrel. The fingers on the sleeve prevent the pump from rotating when the hollow shaft turns. The two wave-profiled rings on the shaft that are fixed onto the pistons are forced down (during $90^{\circ}$ of rotation) by the rollers (replacing the initially used weak ball bearings), pressing the upper piston against a strong spring. The spring then moves the piston up (during the next $90^{\circ}$ rotation) along with a volume of liquid. As the roller shafts are mounted at $90^{\circ}$ and the profile rings are aligned in phase, the two pistons will move in anti-phase. Detail of the roller/wave profiled ring assembly is shown in the inset. In case of packed chips in or on top of the pump, no damage will come to the pump assembly, as the springs will just stay compressed. The circular flap valves ensure the liquid will move upwards as well as ensure free flow through the pump when descending in the hole.

drill head, a situation that can end with a stuck drill. With the pump installed it should be easy to clean the chips from the bottom by lowering the rotating drill slowly so the pump can suck in the chips before touchdown. Initially we planned on having both valves closed and the hollow shaft open while cutting the ice. This configuration works well during drilling but does not work well while cleaning the hole bottom. Cleaning requires the bottom end of the hollow shaft to be closed (e.g. with a spring-loaded ball valve) to prevent the liquid from moving down into the inner barrel and ensure that the circulating fluid goes up the hollow shaft and down the outside of the drill (where cleaning is most needed) and back to the drill head and pump. At the same time the lower valve must be kept open by replacing the upper disc with a ring in order to allow the liquid on top of the core to escape during drilling.

Unfortunately, slow feed-out was not possible with the available winch controller, and the only way to feed cable was to release the brake manually for the shortest possible time. Due to the static friction of the skates, this caused the drill to jump $5-10 \mathrm{~cm}$ when it finally moved. This intermittent method works well when drilling has started, but often fails to clean the hole bottom properly before cutting starts, as the drill must stop immediately above bottom after the final cleaning slack has been given, and this only happens by 'accident'. At NorthGRIP in 1997 these unsolved winch problems resulted in a stuck drill at $1372 \mathrm{~m}$.

A new hole was started at NorthGRIP in 1998 using the dry version of the HT drill for drilling the access hole. The dry

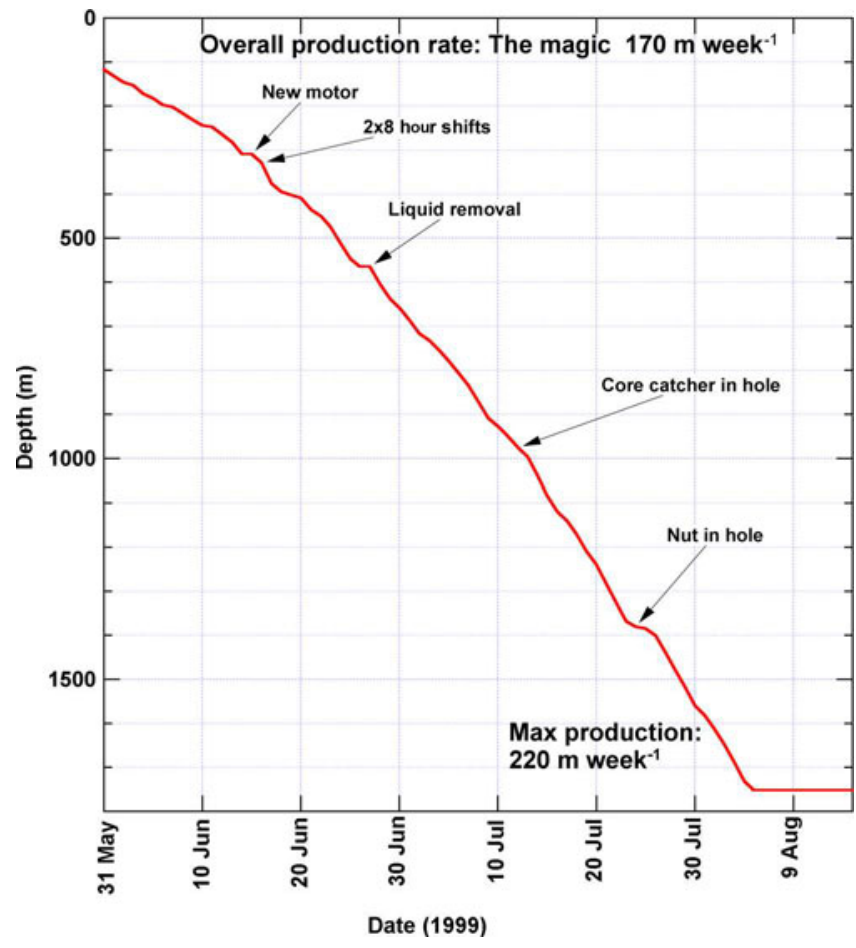

Fig. 8. The NorthGRIP 1999 record core production, $1630 \mathrm{~m}$ in one season. Experiments with a new and 'better' densifier, Sukane 123, had to be aborted, as the densifier was increasingly attached to the chips, with increasing pressure bringing them to the hole bottom and disrupting the drilling process. The new liquid had to be bailed out of the hole at $670 \mathrm{~m}$ depth and replaced with the regular Forane $141 \mathrm{~b}$ densifier mixed in D60. Other problems with the drilling were more regular. Typical features of the production record are that the overall production is $170 \mathrm{~m}^{\text {week }}{ }^{-1}$ during a drilling season and maximum production is found at the end of the drilling season when most encountered problems have been solved and the drilling crews fully trained.

drilling was fast and stable and the hole was plumb to within a fraction of a degree. The much shorter UCPH shallow drill would normally end up with $2-3^{\circ}$ inclination at $100 \mathrm{~m}$.

The next stuck-drill situation came up in the year 2000 at $2930 \mathrm{~m}$ depth, fortunately in quite warm ice; recovery with (pure) ethylene glycol is quite easy. In EDC the drill got stuck twice in spite of a winch controller capable of slow feed. The second time at $786 \mathrm{~m}$ in the $1998 / 99$ season resulted in a lost drill (Augustin and Antonelli, 2002). Due to the very cold temperatures, ethylene glycol would not have released the drill. Many runs were lost on this account, but the drillers could somewhat improve the situation by pulling the drill up fast from the bottom with the upper valve closed before starting to drill, in order to mix the bottom chips with more liquid. It was not until 2003 that we had access to a proper winch controller at NorthGRIP, which helped prevent drill sticking during the difficult warm-ice drilling in 2003 and 2004. In the 2001 season we actually had the drill stuck nearly ten times in the warm ice but fortunately it could be released by dumping a few frozen $100 \mathrm{~g}$ pellets of pure ethylene glycol in the hole. The pellets would melt in the warm, deep part of the hole and find their way to the hole bottom where they dissolved the packing at the drill head to release the drill.

Glycol was thus an important lifesaver for stuck drills. Having glycol in the hole could possibly have 'lubricated' 


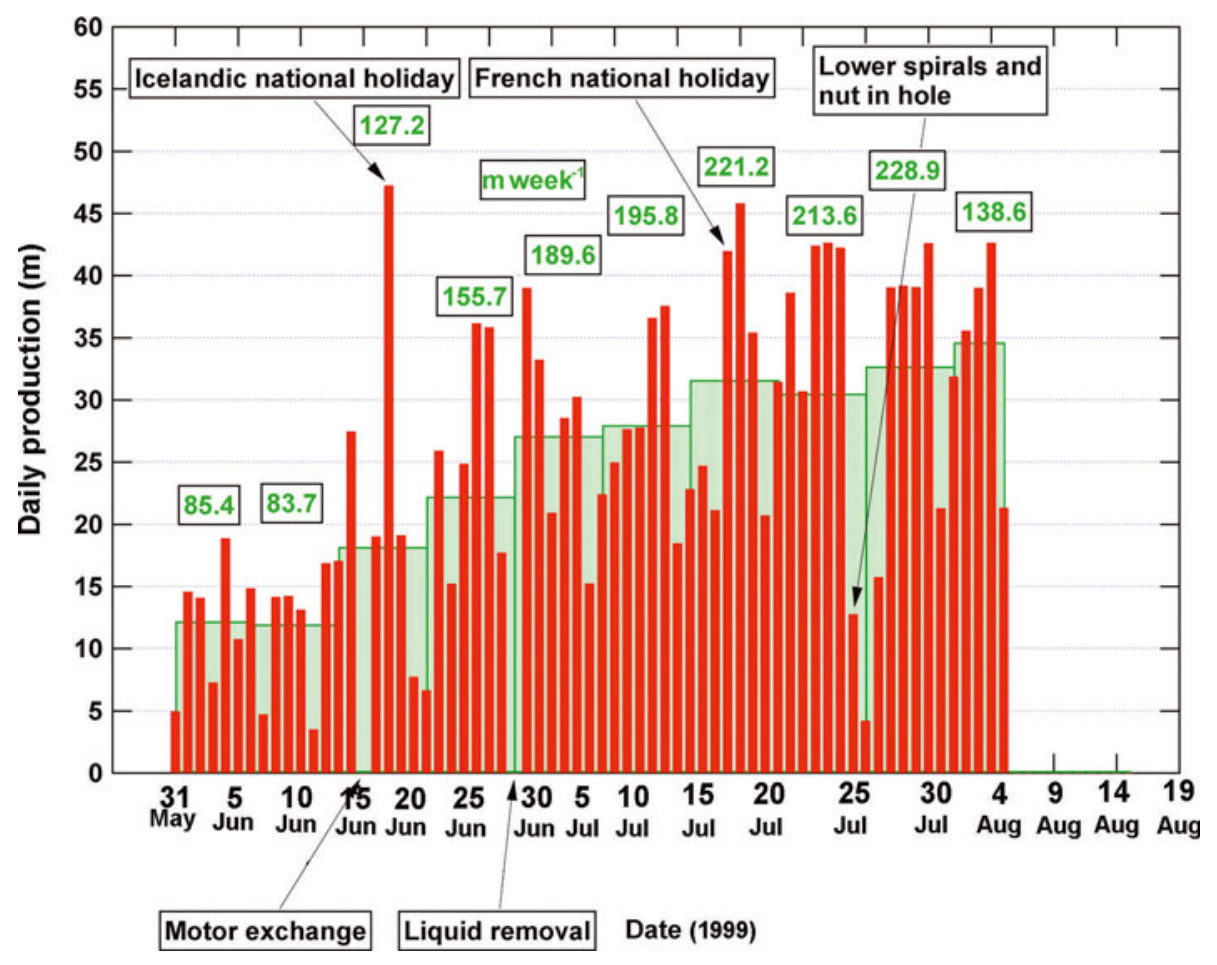

Fig. 9. Daily (red bars) and weekly (green boxed values) production at NorthGRIP 1999. The friendly national competition did not hurt the production rate.

the hole bottom for easier drilling, but eventually when the heavy glycol mixture had dissolved enough ice at the bottom it seemed to become light enough to start moving up into colder ice where it would start freezing out and building annoying glycol/ice bridges that blocked free passage of the drill in the hole (it is also possible that these bridges were leftovers from the 2000 season when an unknown amount of engine antifreeze was dumped in the hole to free the stuck drill).

\section{SPIRALS}

The spirals were initially designed to fill the $4.5 \mathrm{~mm}$ wide clearance between the inner barrel and the inside of the grooved outer barrel for moving the chips upwards during drilling. This works well in dry drilling mode, but in wet drilling mode, with the pump installed, the chips/liquid mixture has to be sucked through the three independent channels between the three spirals; fundamentally a most unstable situation as was discovered during the 1997 drilling at NorthGRIP. Many runs were lost when one of the channels became blocked, resulting in packing at the drill head and an aborted run. The solution to the problem was to install thinner spirals. Initially we used $2 \mathrm{~mm}$ thick wires wound around the core barrel. This worked well, as now there was only one channel leading to the pump and the wires helped stir up the chip/liquid mixture, preventing coagulation of the chips and blocking of the flow. Before installing the wires, an experiment was made to run without any spirals on the core barrel. This failed utterly. Subsequently, the wires were replaced by $2 \mathrm{~mm}$ thick, $10 \mathrm{~mm}$ wide aluminium strips. Another experiment, insisted upon by one of the trainees, was to have the strips end at the centring knobs $10 \mathrm{~cm}$ above the lower end of the inner barrel. In this short interval where the strips were missing, the chips separated from the mixture, resulting in blocked chips transport and immediate packing. The lesson learned was that the chip/liquid mixture needs to be well stirred at all times.

After final tuning of the drill, the 1999 NorthGRIP drilling season produced a record high $1630 \mathrm{~m}$ of good core (Figs 8 and 9). Drilling problems were a little more tricky than expected, but our overall mean core production rate was $170 \mathrm{~m}$ week $^{-1}$.

\section{THE BAYONET COUPLING}

The constant threat of a stuck drill in the NorthGRIP drilling project inspired the $U C P H$ group to design a special coupling between the drill and core barrel as shown in Figures 3 and 10. The aim was twofold. First, in a stuck-drill situation, it would make it possible to leave only the core barrel in the hole if all rescue efforts were in vain. Secondly, the coupling could allow an efficient hammer to release the drill when stuck. This feature, however, needs to be further developed. When the NorthGRIP drill got stuck in 2002 we were not able to release the core barrel, as the friction in the rollers was too high and the shear pin in the gear shaft broke. This pin is a leftover from the ISTUK drill, made necessary by the piston-moving screw, but is not needed in the HT-type drills. To use the super-banger/hammer feature of the coupling requires that the electronics can withstand very high g-forces.

\section{WARM-ICE DRILLING}

Observations made during the GRIP drilling project (Johnsen and others, 1994) showed the formation of refrozen water on the cutters at ice temperatures of $-10^{\circ} \mathrm{C}$ or even colder. The problem did not occur at Dye 3, Greenland, where the 


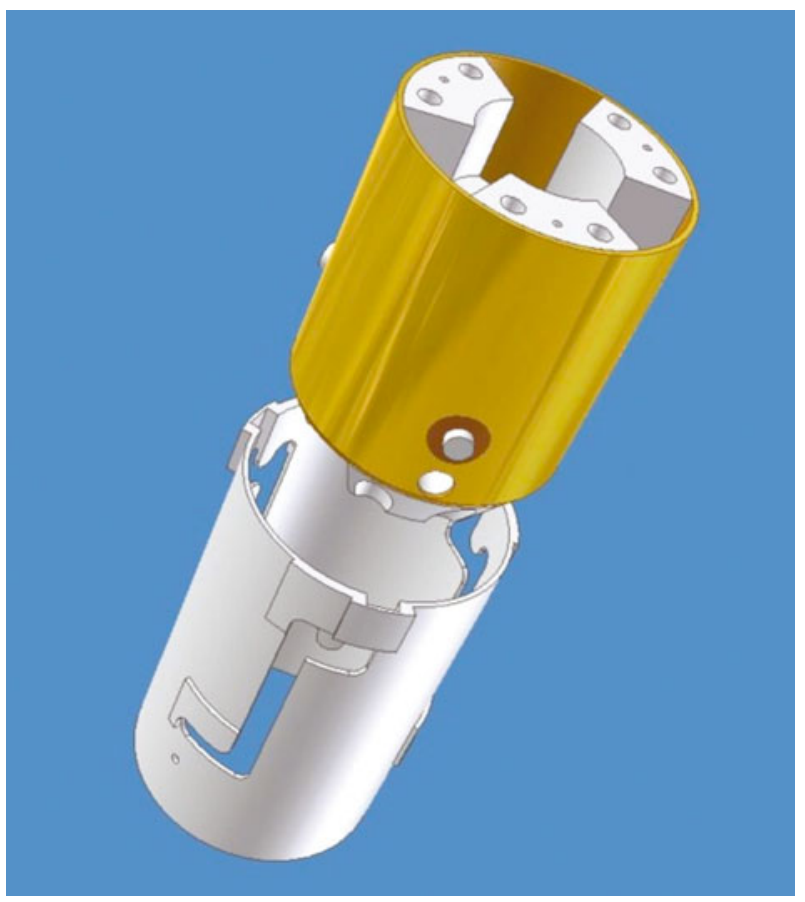

Fig. 10. Bayonet coupling or the super banger. The upper block is attached to the lower end of the hollow shaft, and the sleeve is welded to the top of the core barrel. The three rollers on the block can be latched on, inside the grooves of the sleeve. This way the core barrel can be mounted on or released from the drill at the bottom of the hole or at surface. Another feature can provide heavy impact on the core barrel by pulling hard on the drill with the rollers in the lower left (normal) position and then rotating the drill backwards. This feature still needs to be properly tested but could help to release stuck drills as the main mass of the drill is acting as a hammer.

basal temperature is $-13^{\circ} \mathrm{C}$ (Gundestrup and others, 1984); however, at GRIP, as the ice temperature became warmer, up to the maximum of $-8.5^{\circ} \mathrm{C}$ at the bottom (Johnsen and others, 1995), the cutters produced a great amount of refrozen melt that would frequently build a bridge between the cutters and channels, blocking the chip transport, producing packing and a short or lost run. Drilling in warm ice thus became a real challenge for the NorthGRIP and EPICA drilling projects, as the bottom temperatures at NorthGRIP, Dome $\mathrm{C}$ and DML turned out to be at the pressure-melting point, $\sim-2.4^{\circ} \mathrm{C}$.

The problem was first encountered at NorthGRIP during the 2002 season. We had some ethylene glycol in the hole but it did not seem to ease the meltwater problem (although it certainly helped to release the drill every time it got stuck). Another problem was the sticking of the core in the core barrel due to freezing of the glycol mixture (and later the ethanol mixture) between the core and core barrel during pull-up. The solution was to first heat the entire drill inside a long box with warm air from a Hermann-Nelson blower and, when the core barrel was released, to heat the barrel in a D60 bath to a temperature close to the actual temperature during drilling.

The warm ice became difficult to drill at Dome $C$ in the following, 2002/03, drilling season (Augustin and others, 2007). The drilling group had recommended that ethanol be brought to Dome $\mathrm{C}$ to help cope with the meltwater and subsequent freezing on the drill and core. This turned out to

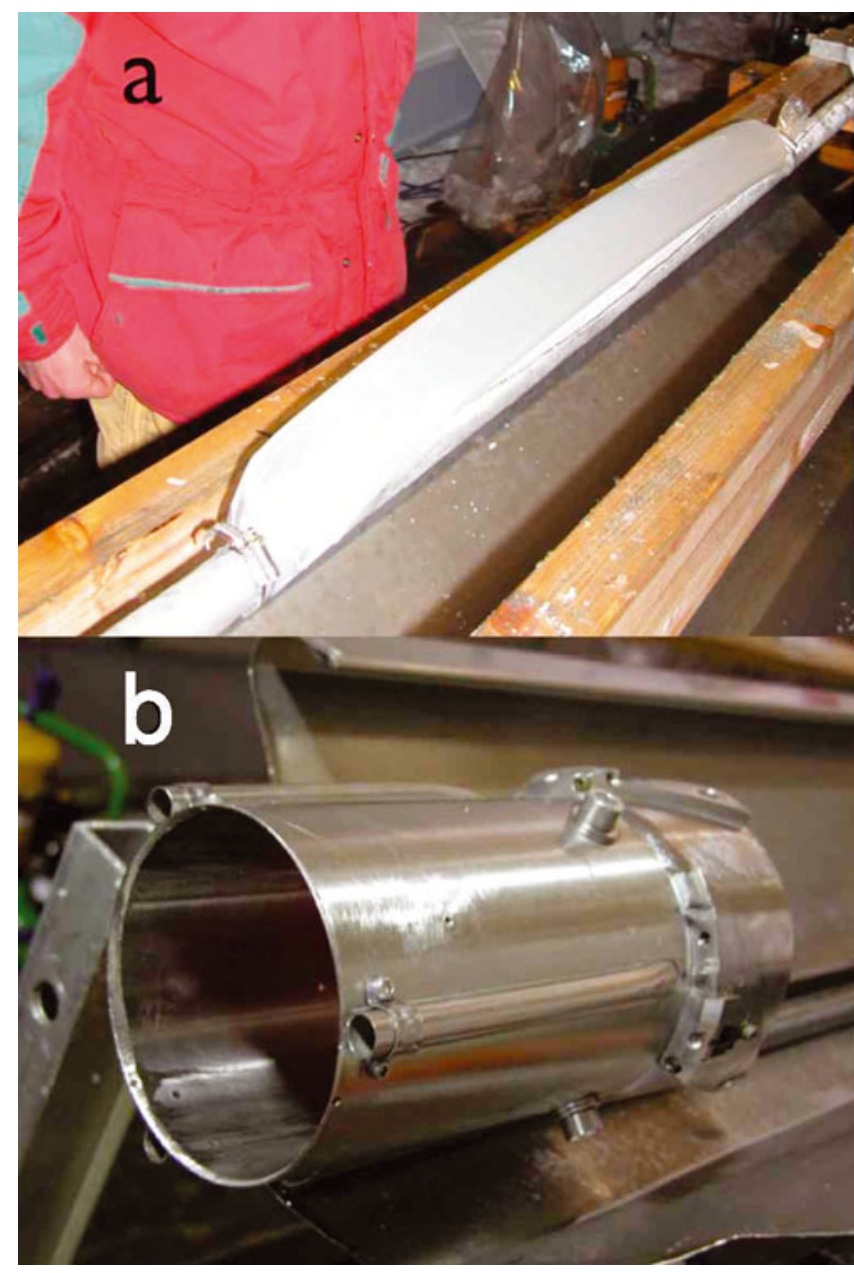

Fig. 11. (a) The 'cognac bomb', a $0.5 \mathrm{~L}$ plastic hose filled with $50 \%$ EWS attached to the hollow shaft with hose clamps. When the motor starts, the hose is ripped open by a removable screw in the chips-chamber wall and the ethanol mixture is circulated down to the drill head, preventing refreezing of meltwater. (b) Before drilling became stable, some non-magnetic nuts and screws had to be removed from the bottom of the hole. This was done using a most efficient vacuum cleaner designed and built by A.Z. It is attached to the drill head, and the pump sucks liquid through the pipes when the drill rotates.

be a most difficult venture as, although the ethanol water solution (EWS), brought to the bottom of the hole, initially helped the drilling, most of the EWS unexpectedly turned into great amounts of ice-ethanol slush obstructing the drilling until it was cleaned out.

At NorthGRIP the warm-ice problem was first seriously attacked in the 2003 season. We brought a heated isolated tank to bring EWS to the bottom and we also brought an ethanol thermal drill (Zagorodnov and others, 2002). We hoped the thermal drill would be ideal for drilling in ice close to the pressure-melting point. Our initial experiments resulted in the following outcome. Firstly, the ethanol brought down to the bottom in the tank behaved much worse than we had expected, eventually turning into slush, inhibiting further proper drilling. Secondly, the spiral heater at the lower end of the thermal drill burned out as soon as the drill touched bottom, most likely due to extremely high voltage (in the megavolt range) between the NorthGRIP camp and the (pink electrolytic) water in the ice matrix in galvanic contact to bedrock. 


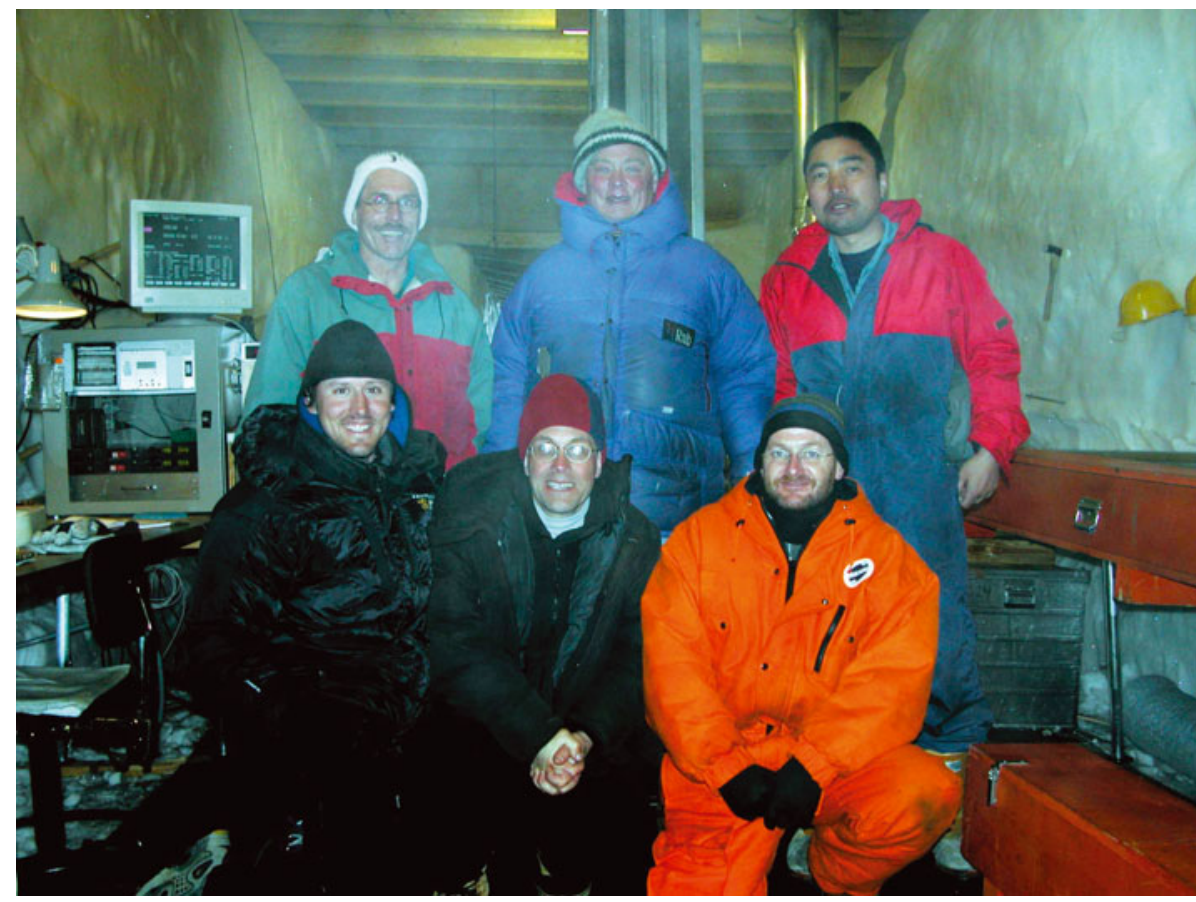

Fig. 12. The NorthGRIP 2003 drillers. Back row (left to right): J. Schwander, S.J. Johnsen and H. Motoyama; front row (left to right): T. Popp, V. Zagorodnov and L. Augustin. Most of the drilling difficulties were over with the 'cognac bomb', as witnessed by the facial expressions.

\section{THE 'COGNAC BOMB'}

Based on the difficulties experienced so far with using EWS to deal with the warm ice, it was decided to deliver only a limited volume, around $0.5-1 \mathrm{~L}$, of about $50 \%$ EWS with the drill in each run. The aim was to drill enough core during the run to recover most of the EWS brought down in the chips chamber to prevent excessive formation of slush. The EWS was stored in a $5 \mathrm{~cm}$ diameter, $0.5 \mathrm{~L}$, plastic hose, the 'cognac bomb' closed with two knobs and clamped to the hollow shaft of the HT drill with hose clamps (Fig. 11a). When the drill motor was started, the plastic hose was ripped open just above bottom by a pointed screw extending through the wall of the chips chamber. The pump would then ensure that the released EWS would circulate down to the drill head and prevent or slow down refreezing of the meltwater produced by the cutters. The drilling, however, did not become stable until some non-magnetic nuts and screws had been removed from the bottom of the hole using a newly built vacuum cleaner (Fig. 11b). The 'cognac bomb' worked much better than earlier experiments with EWS, and the drillers became much happier, as Figure 12 clearly indicates. We were able to drill up to $5 \mathrm{~m}$ of good core daily down to $3085 \mathrm{~m}$ depth, when the bottom meltwater flushed the hole, immersed the drill and shorted the electric connections in the anti-torque section.

In 2004 the drilling was continued in order to recover the $45 \mathrm{~m}$ of refrozen bottom water from the previous year. By using the same ethanol procedure as in the previous year and the same winch controller, the drilling went on in a stable routine and bedrock was reached at $3090.5 \mathrm{~m}, 5.5 \mathrm{~m}$ below the water channel we drilled into the year before.

\section{THE ULTIMATE LESSON LEARNED}

During decades of drilling in polar ice, one lesson we have learned stands out as being the most important. It often happens that a mistake is made or something goes wrong with the mechanics or the electronics. The operator will then quite often be tempted to play the hero and go for a quick fix of the apparent problem. He may be lucky and all goes well, but more often, by not having analyzed the event thoroughly in an open discussion with those who know the system, he will misunderstand the situation and make a wrong decision. Such decisions will frequently produce damage an order of magnitude worse than if a decision had been made based on a sound understanding of the problem. The scenario is like the second-impact damage in a car accident. When bad things happen (and they will), take a break and discuss the problem in the open before any action is taken.

\section{ACKNOWLEDGEMENTS}

We are greatly indebted to the various funding agencies for supporting the projects involved, including the cost of drill development and drilling. We also thank all the logistic people for organizing the field camps and for bringing us there along with our equipment. The numerous drillers who put long cold hours into careful drilling and recovery of good-quality cores are thanked for their vital contribution, and for helping to improve the drills and drilling techniques. Finally we thank the scientific teams for making such good use of the ice cores we managed to deliver. To drill good ice cores against all odds is a most satisfying experience in a well-functioning drilling camp, but to see the final outcome described in high-level scientific papers should also be a fully acceptable reward.

\section{REFERENCES}

Árnason, B., H. Björnsson and P. Theodórsson. 1974. Mechanical drill for deep coring in temperate ice. J. Glaciol., 13(67), 133-139.

Augustin, L. and A. Antonelli. 2002. The EPICA deep drilling program. Mem. Natl. Inst. Polar Res., 56, Special Issue, 226-244. 
Augustin, L., S. Panichi and F. Frascati. 2007. EPICA Dome C 2 drilling operations: performances, difficulties, results. Ann. Glaciol., 47, 68-72.

Dahl-Jensen, D. and 8 others. 2002. The NorthGRIP deep drilling programme. Ann. Glaciol., 35, 1-4.

EPICA Community Members. 2004. Eight glacial cycles from an Antarctic ice core. Nature, 429(6992), 623-628.

EPICA Community Members. 2006. One-to-one coupling of glacial climate variability in Greenland and Antarctica. Nature, 444(7116), 195-198.

Greenland Icecore Project (GRIP) Members. 1993. Climate instability during the last interglacial period recorded in the GRIP ice core. Nature, 364(6434), 203-207.

Gundestrup, N.S., S.J. Johnsen, and N. Reeh. 1984. ISTUK: a deep ice core drill system. CRREL Spec. Rep. 84-34, 7-19.

Hammer, C.U., S.J. Johnsen, H.B. Clausen, D. Dahl-Jensen, N. Gundestrup and J.P. Steffensen. 2001. The paleoclimatic record from a $345 \mathrm{~m}$ long ice core from the Hans Tausen Iskappe. Medd. Grønl. Geosci., 39, 87-95.

Hancock, W.H. 1994. Instrumentation for the PICO deep ice coring drill. Mem. Natl. Inst. Polar Res., 49, Special Issue, 69-77.

Johnsen, S.J., W. Dansgaard, N. Gundestrup, S.B. Hansen, J.O. Nielsen and N. Reeh. 1980. A fast light-weight core drill. J. Glaciol., 25(91), 169-174.

Johnsen, S.J., N.S. Gundestrup, S.B. Hansen, J. Schwander and H. Rufli. 1994. The new improved version of the ISTUK ice core drill. Mem. Natl. Inst. Polar Res., 49, Special Issue, 9-23.
Johnsen, S.J., D. Dahl-Jensen, W. Dansgaard and N.S. Gundestrup. 1995. Greenland paleotemperatures derived from GRIP borehole temperature and ice core isotope profiles. Tellus, $47 \mathrm{~B}(5)$, 624-629.

Mulvaney, R., O. Alemany and P. Possenti. 2007. The Berkner Island (Antarctica) ice-core drilling project. Ann. Glaciol., 47, 115-124.

North Greenland Icecore Project (NorthGRIP) Members. 2004. High-resolution record of Northern Hemisphere climate extending into the last interglacial period. Nature, 431(7005), 147-151.

Suzuki, Y. 1994. Development of Japanese mechanical drills personal reminiscences. Mem. Natl. Inst. Polar Res., 49, Special Issue, 1-4.

Suzuki, Y. and K. Shimbori. 1986. Development of an ice core drill for liquid-filled holes. Mem. Natl. Inst. Polar Res., 45, Special Issue, 86-92.

Tanaka, Y. and 6 others. 1994. Development of a JARE deep ice core drill system. Mem. Natl. Inst. Polar Res., 49, Special Issue, $113-123$

Theodórsson, P. 1976. Thermal and mechanical drilling in temperate ice in Icelandic glaciers. In Splettstoesser, J.F., ed. Ice-core drilling. Lincoln, NB, University of Nebraska Press, 179-189.

Zagorodnov, V.S., L.G. Thompson, E. Mosley-Thompson and J.J. Kelley. 2002. Performance of intermediate depth portable ice core drilling system on polar and temperate glaciers. Mem. Natl. Inst. Polar Res., 56, Special Issue, 67-81. 